\title{
Factors Influence School Readiness of Inclusion Elementary School's Students
}

\author{
Dinni Asih Febriyanti ${ }^{1}$ and Anita Listiara ${ }^{2}$ \\ ${ }^{1}$ Universitas Diponegoro, Semarang, Indonesia \\ dinniasih@gmail.com
}

\begin{abstract}
One of the most important factors influence school achievement of first grade elementary school's student was school readiness. Indonesian government regulation regarding that minimum age for admission to elementary school is 7 years old to gain student's school readiness. School readiness was formed by several internal and external factors. Those factors will be more necessary wheter the elementary school is an inclusion school. Previous researchs had found there were some problems occured on inclusion school. The problems were about teacher's classroom management skill and bullying intension amoung students. This study aimed to investigate correlation between student's intelligence, age at entry school, and parental socio-economic level with student's school readiness. Participants of this correlational study were first grade students of inclusion elementary school $(\mathrm{N}=36)$. Data were collected using Wechsler Intelligence Scale for Children, Nijmegsee Schoolbekwaamheids Test (NST), and school demographical's data (for parental socio-economic and student's age variables). Regression analysis showed there were positive correlation between fullscale IQ score and NST score ( $\mathrm{r}_{\mathrm{xy}}=$ $0.583, \mathrm{p}<0.05)$. Pearson product moment's correlation showed positive correlation between performance IQ and school readiness $\left(\mathrm{r}_{\mathrm{xy}}=0.457, \mathrm{p}<0.05\right)$. There were no correlation between verbal IQ score, student's age, and parental socioeconomic level with school readiness.
\end{abstract}

Keywords: School readiness; Intelligence; Parental socio-economic status.

\section{$1 \quad$ Introduction}

Education in Indonesia is structured as a comprehensive system to develop human potential to have knowledge, mental, and living skills. According to UU (educational decree) No. 20 of 2003 which regulates the education system, education in Indonesia is organized through 3 subsystem, formal, non-formal, and informal. The formal education as the main subsystem had characteristics as structured and stratified system. In accordance with article 6 paragraph 1 of the UU, the government requires all citizens to take primary education. The level of primary education consists of Elementary Schools / Madrasah Ibtidaiyah and Junior High School / Madrasah Tsanawiyah. Government Regulation No. 17 of 2010 as a guideline for implementing the UU states that one of primary education's objective is to provide the basics of intellectual ability which consist of reading ability, writing ability and maths ability.

This prinary education objective was concord to developmental theories in psychology. Erikson's socioemosional development theory reveals that when a child enters formal school, the child bases his behavior on orientation to achieve achievement [1]. At this stage of development, children begin to expect recognition and appreciation for their achievements. Childrens academics achievement at this time will increase their self-esteem and self confidence to obtain the best results in the future [2]. There are a number of predictors that influence student achievement, especially in the first grade of elementary school [3], where one of the most important factors is school readiness [4,5,12].

The initial concept of school readiness states that school readiness is the level of child development to master a number of learning processes and skills accompanied by maturity to integrate these mastery in order to study in school [6,7]. School readiness then develops into more detailed concepts which include: 1) adaptive behavior in managing negative emotions such as anger and feeling depressed;2) language and cognitive skills such as communicating, reading and writing, and getting to know the surrounding environment; 3) self-help skills such as eating-drinking, toilet activities, working independently and asking for help from others; and 4) the availability of support from families such as getting support and prayer, having a routine at home, and having a habit of reading at home [8].

School readiness as an important factor to support the success of student learning have big influence, both on academic abilityaspect and personality aspects. Previous research on students with low socioeconomic backgrounds and immigrant families reported that writing and numeracy exercises given during preschool could be a predictor of various aspects of performance at the beginning of elementary school and various aspects of reading and math skills in third grade, levels where lessons begin to being abstract $[9,10]$ School readiness also contributes to a number of student personality aspects; including self-regulation ability [11], social competence [12], and the school socialization skills [13]. 
Indonesia government also pay serious attention on school readiness of Indonesian students. According to Educational ministry regulation (Permendikbud) No. 17 of 2017 the government set a minimum age limit for elementary school entry is 7 years. Prospective students aged 6 years can be accepted if there is still an acceptance quota after all applicants aged at least 7 years have been declared accepted. In the next academic year, through Permendikbud no. 14 of 2018 added rules for prospective students who are less than six years of age can be accepted if they have reached the age of five years and six months with the conditions accompanied by a recommendation letter from the psychologist. The application of this Permendikbud gave the effect of reducing the proportion of prospective students under 7 years of age who are accepted as elementary school students in Central Java Province. Central Java Province Education Agency recorded data in the 20162017 academic year, the number of new elementary school students under the age of 7 reached a percentage of $0.67 \%$ of all students. This percentage is reduced in the 2017-2018 academic year where the number of new students under the age of 7 only reaches $0.12 \%$. This percentage showed that there are children who were already in elementary school before 7 years of age.

Previous research has linked students' entry age to school readiness. Research on 405 public school students in Virginia shows students entering kindergarten at the age of five years continually get a higher score in the reading and writing ability tests to sit in grade 2 elementary school than students entering the park Children at a younger age [14].

Parental socioeconomic is the next factor that influences children's school readiness. Research showed that parental socioeconomic aspects consist of parents psychological well-being [15], parent's marital status and the child's living environment [16], and the location of the child residence [17]. Parental level of education as a part of parental socio-economic conditions also contributes to the children's school readiness. A longitudinal research of non-special needs children in United States showed children whose their parents education level lower than under graduate degree had numerous problems related on school readiness [18]. The majority of problems reported were behavioral problems and low academic achievement. The level of parental education is also associated with the ability to earn more income to meet physical needs and provide stimulation of child development [19].

Parental socio-economic conditions are often positioned as external factors that influence school readiness [2]. External factors also including physical environmental conditions of children's learning places [20] and parental involvement [21]. While internal factors that also influence childrens school readiness are children socialization skills [22] and the students' intellectual abilities [23]

Intelligence is often associated with individual learning outcome. Children who have higher level of intelligence are predicted to have a higher probabilities to being success. This important role of intelligence can be seen from various capability variables which are the scope of intelligence concepts. Stenberg [in 1] argues that the scope involves a) the context of the environment in which intelligence behavior appears, b) previous experience to carry out certain tasks, and c) cognitive processes needed to complete the task.

Accordance to Article 4 of Government Regulation (PP) No. 70 of 2009 each regency in Indonesia is required to appoint at least one elementary school and junior high school as the organizer of inclusive education. This regulation increases the number of inclusive schools in various locations in Indonesia. The data obtained by the authors indicate that since this regulation was implemented until the 2015-2016 school year, the number of inclusive schools at the junior high school level throughout Indonesia has reached 3,817 schools [24]. A number of studies show that the implementation of inclusive education still causes problems. This problem is related to the low ability of teachers in classroom management [25], the attitude of the teacher and the school in facing parents' refusal of regular students towards students with special needs [26], as well as the bullying tendency of regular students to students with special needs. If it is associated with a new concept of school readiness covering both academic and non-academic aspects, the conditions of inclusive education can provide a different picture of school readiness in inclusive schools. Based on those background, this study focuses on investigations about school readiness for students who sit on the primary school level of inclusion in terms of age, intelligence, and socioeconomic status of parents.

\section{Literature Review}

The opportunity to develop school readiness has the aim of encouraging children's ability to successfully transition to school life and prevent bad adjustments to schools, for example academic failure, no employment, and poverty [28]. According to Lunenberg [in 28], there are three important influences of parents on adjusting children to school, that is, the expectation of parents to succeed in going to school, cognitive stimulation that children receive when at home, and interaction between parents and children. Therefore, students who attend pre-school education tend to have better academic performance [29].

Children's school readiness was not an innate factor of the child. Their skills and development are strongly influenced by the family and their interactions with others, and the environment around them before they go to school [30]. The study was conducted on students from regular schools using exclusion criteria for students with special needs. The results of this study are consistent with the findings which state that the level of school readiness of students who have parents who are involved in the development of their children appear to be higher than students with parents who have less involvement in the development of their children [31].

In the viewpoint of developmental psychology and educational psychology, the role of the environment in the quality of child development can be explained through the Bronfenbrenner theory. According to this theory, the child and the 
surrounding environment are predictors of the child's growth and development [2]. The predictor forms a circular, layered system. Children become a core circle in the multilevel system. All innate characteristics and abilities of children are found in this core circle. The environment around the child is divided into 6 layers of circles [1]. The first layer is called a microsystem, which includes an environment that routinely deals with children, namely family, neighbors, and schools. The second layer is called the mesosystem which includes interactions between elements in the microsystem. The third layer is an ecosystem which is an environment that is not directly related to students but affects the lives of students such as friends from family, mass media, and legal entities. The outermost layer is macrosystem which is a system of values, culture, and beliefs that color a child's life. While the time changes that occur throughout the child's growth are chronosystem. This theory has a micro context from the child's daily life to the macro context of the global situation that occurs during the child's development.

\section{Material \& Methodology}

\subsection{Methods}

This study uses a quantitative approach with the design of correlational survey methods. The variables in this study are school readiness as dependent variables as well as intelligence, chronological age, and parental socioeconomic status as independent variables.

\subsection{Data collection}

All students in grade 1 of the inclusive elementary school $(\mathrm{N}=36)$ who participated in this study followed the series of WISC intelligence test procedures as well as the filling of the school readiness instrument for Nijmeegse Schoollbekwaamheids Test (NST). Chronological age data of students and socio-economic status of parents are obtained through student's demographic data of school. The implementation of the WISC intelligence test refers to the WISC manual that accompanies the test tool. All students take 11 WISC subtests, consist of 5 verbal intelligence subtests and 6 performance intelligence subtests. Verbal intelligence subtests consist of information subtest, comprehension subtest, arithmatic subtest, similarities subtests, and vocabullaries subtest. Performance intelligence subtests consist of picture completion subtest, picture arragement subtest, blocks design subtest, objects assembly subtest, digit span subtest and mazes.

\section{Results and Discussion}

\subsection{Result}

Data processing calculations were carried out on school readiness variables (NST scores), intelligence level variables (total IQ scores, verbal IQ scores, and WISC IQ performance scores), age variables, and parents' socioeconomic level variables (parental education level category). Based on the results of statistical analysis, only school readiness variables and total IQ scores have normal distribution. Correlation test results through the calculation of regression analysis between total IQ scores and school readiness showed a positive relationship between total IQ scores and school readiness with $r=0.583(p<0.05)$. The total IQ score as an illustration of the level of intelligence of students has a contribution of $34 \%$ to the school readiness of students.

Table 1. Regression analysis total IQ scores and school readiness

\begin{tabular}{|l|l|l|l|l|}
\hline & & & & \\
Model & R & R Square & Adjusted R Square & Std. Error of the Estimate \\
\hline 1 &, $583^{\mathrm{a}}$ &, 340 &, 320 & 8,164 \\
\hline
\end{tabular}

Correlation test through Pearson correlation calculation between verbal IQ scores and school readiness shows there is no relationship between the two variables with $\mathrm{r}=0.551(\mathrm{p}=0.152)$. While the results of the correlation test through the calculation of Pearson correlation shows that there is a relationship between IQ performance scores and school readiness students with $r=0.457$ ( $p<0.05$ ). Pearson correlation test between age and school readiness shows that there is a negative relationship between the two variables with $r=-0.389(\mathrm{p}<0.05)$. While the Pearson correlation test for socioeconomic level variables with school readiness shows no relationship between the two variables with $r=-0.66$ ( $p=$ 0.352). Chi square test of school readiness between regular students with special needs students showed that school readiness of regular students is higher than school readiness for students with special needs with chi-square $=8.267$ ( $\mathrm{p}=$ $0.004)$. 
Table 2. Pearson correlation calculation of school readiness

\begin{tabular}{|c|c|c|c|c|c|c|c|c|}
\hline \multirow{2}{*}{} & \multicolumn{2}{|c|}{ IQ verbal } & \multicolumn{2}{c|}{ IQ Performance } & \multicolumn{2}{|c|}{ age } & \multicolumn{2}{c|}{ economic } \\
\cline { 2 - 9 } & $\mathrm{r}$ & $\mathrm{sig}$ & $\mathrm{r}$ & $\mathrm{sig}$ & $\mathrm{r}$ & $\mathrm{sig}$ & $\mathrm{r}$ & sig \\
\hline Kesiapa & 0. & 0.152 & 0. & 0.000 & - & 0.004 & - & 0.352 \\
$\mathrm{n}$ & 55 & & 45 & & 0. & & 0. & \\
bersekol & 1 & & 7 & & 38 & & 66 & \\
ah & & & & & 9 & & & \\
\hline
\end{tabular}

\subsection{Discussion}

The results showed that there was no correlation between verbal IQ scores and school readiness, however, there is a correlation between IQ performance scores and school readiness. These results illustrate that participants' school readiness is not related to the ability to remember, the ability to express ideas verbally, numeracy skills, comprehension skills, and logical thinking skills. However, it is more related to the ability to concentrate on completing tasks, managing their ownself, motivation and emotions, and managing motor visual coordination. This finding is in accordance with the results of research by Eisenberg, Valiente, \& Eggum [32] that going to school is not only to understand formulas, to count, or to be good at speaking but also to manage oneself to deal with social situations in society and the environment. Therefore, policy holders are expected to develop a curriculum that considers the ecological environment of students [33].

The correlation between intelligence and school readiness is related to the concept of school readiness that underlies the construction of NST test. The concept of school readiness that underlies the development of this test tool is cognitive readiness. This correlation corresponds to Mariyati and Affandi's [34] study of psychometric property analysis using NST to measure children's school readiness in Indonesia. The results of factor analysis in the study showed that 10 subtests in the NST test can be classified into two main factors, namely the dimensions of the critical thinking process and the dimensions of memory / memory ability. Both dimensions were unitary variable or measure the similar variables, namely cognitive maturity.

Previous research [35] has used at least three components in revealing school readiness, which consist of children's readiness to attend school, the readiness of the school intended to accept the presence of children, and the readiness of the family and community to provide facilities to optimize children's development and learning. Based on this concept, it can be recommended the construction of a school readiness measurement tool that accommodates these three components by considering the scope of Indonesian culture.

This recommendation also needs to be based on a more in-depth study of the concept of school readiness that underlies the construction of the tool. The difference in correlation between verbal IQ scores and IQ performance scores on school readiness in this study is consistent with the findings of research on the validity of the Bracken School Readiness Assessment construct. School readiness measurement tools developed for Spanish-speaking students taking into account local cultural settings. The results of the study [36] showed a significant moderate correlation between nonverbal intelligence and school readiness. This finding is in line with the results of this study that verbal IQ scores do not correlate with school readiness, but IQ performance scores have a positive correlation with school readiness. Determination of the level of intelligence or IQ score of the WISC test tool is carried out based on norms arranged according to age level (Gregory, 2010). This administrative procedure is based on conceptual consideration of age as a determinant of the level of individual intelligence. Therefore, it can be understood that there is no correlation between age and school readiness because age has been calculated to determine the score of student intelligence. If linked to the results of previous studies [37], children over the age of six (72 months) were found to have higher school readiness compared to the younger group (66-71 months and 6065 months). These results further strengthen government regulations regarding the minimum age for entering school.

Socio-economic level is not related to school readiness. In the context of support for children's academic success, [38] suggests that parents have at least six forms of involvement. The six forms of involvement consist of: care based on knowledge and skills, communication with the school, participating in teaching at school, supporting learning at home, assisting in children's decision making, working with the community. Therefore, it takes a variety of parental skills, not only high education. The challenge is greater for parents of children with special needs. Therefore, school readiness for regular students is generally higher when compared to students with special needs.

\section{Conclusion}

The conclusion that can be drawn from this study is that intelligence is not the main factor that influences the school readiness of inclusion elementary school students. Socio-economic factors are not only limited to the level of parental 
education. Future research needs to enlarge the number of subjects by considering the various special needs of inclusive students. Their different conditions with regular students also requires different attention and teaching strategies.

\section{Acknowledgement}

This research is fully funded by Faculty Psychology of Universitas Diponegoro Grant. We are fully grateful to all students and teacher of SD DM who participated in this study, and the principal of SD DM who so cooperatively worked with us. We thank Olif, Dian, Niza, Nanda, for their kind assistance in organizing this study and data collection. We also thank to our family for their love and support, and also to our collegues Diana Rusmawati and Ja ti Ariati for their kind discussion about our data collection and data analysis.

\section{References}

1. J.E. Ormrod, Psikologi Pendidikan : Membantu Siswa Tumbuh dan Berkembang. Jakarta : Erlangga, 2008.

2. J.W. Santrock, Educational Psychology, fifth edition, New York : McGroww-Hill Inc, 2011.

3. R.E. Izzaty, Y. Ayriza, and F.A. Setiawati, "Prediktor prestasi belajar siswa kelas 1 sekolah dasar," Jurnal Psikologi, 44, 2, 153164, 2017.

4. R.C. Pianta, M.J. Cox, and K.L. Snow, School readiness and the transition to kindergarten in the era of accountability. Baltimore, MD : Brookes, 2007.

5. G.J. Duncan, C.I.Dowsett, A. Claessens, K. Magnuson, A.C.Huston, P. Klebanov, C. Japel, School readiness and later achievement. Developmental Psychology, 43, 6, 1428-1446, 2007.

6. A.R. Jensen, Understanding readiness: an occacional paper. Urbana, Illinois : ERIC Clearing House on Early Childhood Education, 1969.

7. C.P. Li-Grining, E. Votruba-Drzal, C. Maldonado-Carreno, and K. Haas, "Children's early approaches to learning and academic trajectories through fifth grade". Developmental Psychology, 46, 1062-1077, 2010.

8. C.Hughes, I.Daly, S. Foley, N. White, and R.T. Devine, "Measuring the foundations of school readiness: Introducing a new questionnaire for teachers - The Brief Early Skills and Support Index (BESSI)", British Journal of Educational Psychology, 82, 332-356, 2015.

9. L. Manfra, C. Squires, L.H.B. Dineheart, C.Bleiker, S.C. Hartman, A. Winsler, "Preschool writing and premathematics predict Grade 3 achievement for low-income, ethnically diverse children", The Journal of Educational Research, 1-10, 2016.

10. T.Tavassolie, C. Lopez, J.D. Feyter, S.C. Hartman, and A. Winsler, "Migrant preschool children's school readiness and early elementary school performance", The Journal of Educational Research, 1-10, 2016.

11. C. Blair, and C.C. Raver, "School Readiness and Self-Regulation: A Developmental Psychobiological Approach", The Annual Review of Psychology, 66, 12.1-12.21, 2014.

12. T.J. Sabol, and R.C.Pianta, "Recent trends in research on teacher-child relationship". Attachment and Human Development, 14,3,213-231,2012.

13. L.C. Taylor, J.D. Clayton, \& S.J.Rowley, “Academic socialization : Understanding parental influences on children's schoolrelated development in the early years," Review of General Psychology, 8, pp 163-178, 2004.

14. F.L. Huang, and M.A. Invermizzi, "The Association of Kindergarten Entry Age with Early Literacy Outcomes", The Journal of Educational Research, 105:6, 431-441, 2012.

15. E.Hur, C.K. Buettner, and L.Jeon, "Parental Depressive Symptoms and Children's School Readiness: The Indirect Effect of Household Chaos", Journal Child Family Study, 24, 3462-3473, 2015.

16. S.H.C. Son, and M.F. Peterson, "Marital Status, Home Environments, and Family Strain: Complex Effects on Preschool Children's School Readiness Skills", Infant and Child Development, 26, 2017.

17. Y. Gan, L.Meng, and J.Xie "Comparison of school readiness between rural and urban chinese preschool children", Social Behavior and Personality, 44, 9, 1429-1442, 2016.

18. B.B. Nelson, R.N. Dudovitz, T.R. Coker, E.S. Barnet, C.Biely, N.Li, P.G.Szilogyi, K.Larson, N.Halfon, F.J.Zimmerman, and P.J.Chung, "Predictors of Poor School Readiness in Children Without Developmental Delay at Age 2", Pediatrics, 1, 38, 2 , 1-12, 2016.

19. A.D. Johnson, A.Martin, and J.B. Gunn, "Child-Care Subsidies and School Readiness in Kindergarten", Child Development, 84, 5, 1806-1822, 2013.

20. M.F. Shaari, and S. Ahmad, "Physical learning environment : impact on children school readiness in malaysian preschools", Procedia-Social and Behavioral Sciences 222, 9-18, 2016.

21. S.M. Magdalena, "The effects of parental influences and school readiness of the child", Procedia-Social and Behavioral Sciences 127,733-737, 2014

22. B. Soydan, "Some variables predicting the school readiness of preschool children", Journal of Faculty of Educational Sciences Ankara University, 50(1), 189-208, 2017.

23. H. Jeon, C.A. Peterson, S.Wall, J.J.Carta, G.Luze, E.M.Ezbaugh, M. Swanson, "Predicting school readiness for low-income children with disability risks identified early", Exceptional Children. 77(4), 435-452, 2011.

24. Kementerian Pendidikan dan Kebudayaan, Gambaran sekolah inklusif di Indonesia (Tinjauan Sekolah Menengah Pertama), 2016.

25. N. Tarnoto, "Permasalahan-permasalahan yang dihadapi sekolah penyelenggara pendidikan inklusi pada tingkat SD", Humanitas, 13,1,50-61, 2016. 
26. Ni'matuzahroh “Analisis kesiapan guru dalam pengelolaan kelas inklusi”, [Seminar Psikologi dan Kemanusiaan, Psychology Forum UMM, 2015].

27. U. Hasanah, Ni'matuzahroh, and Y. Nurhamida, "Sikap siswa reguler terhadap siswa berkebutuhan khusus dan kecenderungan bullying di kelas inklusi”, Jurnal Unisia,37,82, 88-102, 2015.

28. F.C. Lunenburg, "Early childhood education: implication for school readiness", Schooling,2,1,2011.

29. M. Yuksel, E.K.Kucukoglu, and F.O.Unsal, "Analysing the school readiness of preschoolers from the aspect of the social skills when they start primary school", International Journal on New Trends in Educations and Their Implications, 4,2,10,98-112,2013.

30. S. Missal, "A survey on school readiness among preschoolers". The Indian Journal of Occupational Therapy, 45, 2, 15-20, 2012

31. R.M.Majzub, and A.R.Rashid, "School readiness among preschool children", Procedia-Social and Behavioral Sciences, 46, 3524$3529,2012$.

32. N.Eisenberg, C.Valiette, and N.D. Eggum, "Self-regulation and school readiness", Early education and development, 21,5,681698,2010 .

33. A.K. Walker, and D.MacPhee, "How home gets to school : parental control strategies predict children's school readiness", Early Childhood Research Quarterly, 26, 355-364, 2011.

34. L.I. Mariyati, and G.R. Affandi, "Tepatkah nijmeegse schoolbekwaamheids test (nst) untuk mengukur kesiapan sekolah siswa sekolah dasar awal pada konteks indonesia? (analisis empirik berdasar teori tes klasik)”, Jurnal Ilmiah Psikologi Terapan, 04, 02, 194-211, 2016.

35. S.Dockett, B.Perry,E and E.Kearney, "School readiness : what does it mean for indigenous children, families, schools, and communities?", Closing the Gap Clearing House, 2, 2010.

36. A.Ortiz, A. Clinton, and B.A. Schaefer, "Construct validity evidence for bracken school readiness assessment, third edition, spanish form scores", Psychology in the Schools, 52, 208-221, 2015

37. H.V. Bayraktar, and M. Kendirci, "Investigation of primary school students' school readiness levels", International Journal of Eurasia Social Sciences, 9, 31, 808-853, 2018.

38. G.S. Morrison, Dasar-dasar Pendidikan Anak Usia Dini (PAUD). Jakarta : PT. Indeks, 2012. 